\title{
PENGARUH LAMA PENYATUAN DAN SAMBUNG SISTEM KAKI GANDA TERHADAP PERTUMBUHAN BIBIT DURIAN (Durio zibethinus, L.) DI KABUPATEN JEMBER
}

\author{
The Old Effect Of Combination And Connection Of Double Feet Systems On The Growth Of \\ Durian Breed (Durio zibethinus, L.) In Jember Regency \\ Mohamad Zaedan Fitri dan Muhammad Islahuddin \\ Program Studi Agroteknologi, Faperta Universitas Islam Jember \\ e-mail : ${ }^{1}$ mohamad_zaidan@ymail.com, ${ }^{2}$ ishla_hi@yahoo.com
}

\begin{abstract}
ABSTRAK
Penelitian ini dimaksudkan untuk mengetahui pengaruh lamanya penyatuan batang utama dengan batang tambahan dan sambung sistem kaki ganda terhadap pertumbuhan bibit durian (Durio zibethinus L.). Penelititian dilaksanakan di desa Sumberjambe kecamatan Sumber Jambe, kabupa ten Jember, yang diaksanakan dari tanggal 20 Mei 2018 sampai dengan tanggal 31 Agustus 2018. Metode penelitian menggunakan Rancangan Acak Kelompok (RAK) yang terdiri dari 2 faktor dan 3 ulangan. Perlakuan masing-masing faktor adalah sebagai berikut; Faktor I adalah lamanya proses penyatuan sambungan bibit durian (L) terdiri dari 3 yaitu: L1 : Penyatuan batang utama dan batang tambahan hari ke 40, L2 : Penyatuan batang utama dan batang tambahan hari ke-60, L3: Penyatuan batang utama dan batang tambahan hari ke 80. Faktor ke II : pemakaian jumlah kaki ganda (P) terdiri dari 4 level, yaitu: P1 : Perlakuan dengan menggunakan 1 batang kaki, P2 : Perlakuan dengan menggunakan 2 batang kaki, P3 : Perlakuan dengan menggunakan 3 batang kaki, dan P4: Perlakuan dengan menggunakan 4 batang kaki. Hasil penelitian perlakuan penambahan kaki ganda memberikan pengaruh yang berbeda sangat nyata terhadap tinggi bibit durian, diameter batang dan jumlah daun pada umur 80 hari setelah sambung kaki (P3) memberikan pengaruh yang sangat nyata. Perlakuan pada umur 40 hari dan 60 hari setelah sambung kaki parameter tinggi bibit, diameter batang dan jumlah daun tidak memberikan pengaruh pada pertumbuhan bibit durian. Tidak terdapat interaksi antara penambahan kaki ganda dan lamanya penyatuan terhadap pertumbuhan bibit durian.
\end{abstract}

Kata Kunci : Bibit durian, lama penyatuan batang, kaki ganda,.

\section{ABSTRACT}

This study aims to determine the effect of the duration of the union of the main stem with additional stems and the connection of the doubleleg system to the growth of durian (Durio zibethinus L.) seedlings. The research was conducted in Sumberjambe village, Sumber Jambe sub-district, Jemberdistrict, which was held from May 20, 2018 to August 31, 2018. The research method used was a Randomized Block Design (RBD) consisting of 2 factors and 3 replications. The treatment of each factor is as follows; Factor I is the length of the process of joining durian (L) seedlings consisting of 3, namely: L1: Unification of main stem and 
additional stem on day 40, L2: Unification of main stem and additional stem 60th day, L3: Unification of main stem and additional stem day 80. Factor II: the use of the number of double legs $(P)$ consists of 4 levels, namely: P1: Treatment using 1 leg stem, P2: Treatment using 2 legs, P3: Treatment using 3 legs, and P4: Treatment using 4 legs. The collected data was analyzed descriptively statistically. Based on the results of the study the effect of the addition of double feet and the length of union to the growth of durian seedlings was concluded as follows, the treatment of adding double feet gave a very significant different effect on durian seedling height, stem diameter and number of leaves at 80 days after foot connection very real. Treatment at the age of 40 days and 60 days after connecting the parameters of seedling height, stem diameter and number of leaves did not influence the growth of durian seedlings. There is no interaction between the addition of double feet and the length of the union to the growth of durian seedlings.

Keywords: Durian seedlings, long union of rods, double legs.

\section{PENDAHULUAN}

Tanaman durian merupakan tanaman buah berupa pohon. Tanaman durian semula berupa tanaman liar yang berasal dari hutan Malaysia, Sumatera, dan Kalimantan. Buah durian sangat digemari hampir semua orang. Penyebaran durian ke arah barat adalah Thailand, Birma, India, dan Pakistan. Buah durian sudah dikenal di Asia Tenggara sejak abad 7 M. Nama lain durian adalah duren (Jawa, Gayo); duriang (Manado); dulian (Toraja), rulen (Seram Timur) (Wijaya, 2013).

Jawa Timur merupakan provinsi dengan produksi durian terbesar di Indonesia pada Tahun 2013. Sebaran produksi durian terbesar di Jawa Timur terdapat di 5 kabupaten. Kabupaten dengan produksi durian terbanyak adalah Kabupaten Pasuruan dengan produksi 84.670 ton atau $53,47 \%$ dari total produksi durian Provinsi Jawa Timur. Kabupaten penghasil durian terbesar lainnya di Jawa Timur adalah Kabupaten Trenggalek dengan produksi sebesar 24,990 ton (15,78\%), Kabupaten Malang 15.140 ton (9,56\%), Kabupaten Bondowoso 11.196 ton $(7,07 \%)$, dan Kabupaten Jember 7.653 ton $(4,83 \%)$. Sedangkan sisanya sebesar 9,28\% (14.695 ton) merupakan kontribusi dari kabupaten lainnya (Pusat Data dan Sistem Informasi Pertanian, 2014)

Di kabupaten Jember daerah penghasil durian kelas I adalah di Kecamatan Sumberjambe. Di Sumberjambe ini banyak dijumpai pohon-pohon durian, bahkan dari daerah ini ditemukan varietas unggul durian yang telah memenangkan kontes-kontes durian mulai nasional sampai internasional.

Durian dari Sumberjambe ini memang sudah menjadi ikon kabupaten Jember karena memang mempunyai rasa yang khas dan harganya cukup terjangkau di kantong pembeli. Tanaman durian Sumberjambe merupakan tanaman lokal sehingga memiliki rasa yang khas yaitu manis, legit dan sedikit pahit. Aroma, bentuk buah, warna kulit dan watna daging juga berbeda-beda. Hal ini yang membuat durian sumberjambe terkenal. Bentuk durian yang beragam ini mempunyai nama sendiri-sendiri ada yang dinamakan durian kerbau, durian gading dan lain-lain. Tanaman durian di Sumberjambe mencapai $(40.000$ - 50.000) pohon dengan jumlah tanaman produktif sekitar $(40-50) \%$ yang tersebar di semua desa di 
kecamatn Sumberjambe utamanya desa Plerean, Rowosari, Pringgondani, dan Jambearum. Durian Sumberjambe ini lebih dikenal dan sudah diadakan beberapa kali kontes, bursa atau pameran di kabupaten Jember. Selain itu pula petani-petani durian juga diikutkan pameran di daerah lain sampai ke Jawa Barat (Jember Information Centre, 2015).

Durian tumbuh dengan baik di daerah tropika basah dengan curah hujan. 2000 $\mathrm{mm} / \mathrm{tahun}$ dan tersebar merata sepanjang tahun dengan lama bulan basah 9-10 bulan/tahun dan $(1-2)$ bulan kering sebelum berbunga. Intensitas cahaya $(40-50) \%$, dengan suhu $(22-$ 30) ${ }^{\circ} \mathrm{C}$. Durian merupakan tanaman tropis yang bernilai ekonomis cukup tinggi untuk meningkatkan pendapatan petani, devisa negara, dan kebutuhan agribisnis. Pertanaman durian yang ada saat ini umumnya berasal dari benih yang kualitasnya sangat beragam. Penyediaan bibit unggul sangat di perlukan untuk menunjang perluasan pertanaman durian, sehingga produksi durian di Indonesia bisa bersaing dengan durian luar negeri. Dalam konteks ekonomi, ketersediaan bibit yang bermutu yang tinggi, mutlak diperlukan sebab bibit harus mampu menghasilkan tanaman yang dapat berproduksi dengan maksimal.

Proses pembibitan yang memakan waktu membuat petani lebih memilih langsung membeli bibit tanaman buah.Jika para petani pembudidaya buah memilih melakukan pembibitan maka petani akan menjalani dua tahap yaitu pembibitan dan penanam. Para petani pembudidaya cenderung melakukan penanaman bibit yang dibeli langsung dari penangkar tanaman buah.Untuk mendapatkan bibit yang baik dan mampu berproduksi dengan baik serta cepat berbuah, maka diperlukan perbanyakan bibit. Perbanyakan bibit dapat dilakukan secara vegetatif, antara lain dengan cara sambung pucuk, sambung sisip, okulasi dan cangkok. Seiring berkembangnya ilmu pertanian maka, untuk memperoleh bibit tanaman buah dapat memakai sistem kaki ganda yang bertujuan untuk mempercepat pertumbuhan tanaman.

Cara perkembangbiakan dengan cara kaki ganda ini memiliki nilai seni yang tinggi dan pertumbuhannya akan optimal. Kaki ganda ini merupakan penambahan batang bawah lebih dari satu yang menyerupai sambung susuk. Batang bawah (root stock) biasanya berasal dari biji (seeding) lokal yang sudah mampu berdaptasi dengan kondisi iklim dan tanah bawaan setempat, selain itu kaki tanaman juga bisa diganti dengan tnaman lain yang serumpun. Kaki ganda bisa diaplikasikan pada hamper semua jenis tanaman tahunan, karena dianggap bisa memberikan manfaat pada tanaman seperti, perakaran semakin kuat dan luas, sehingga bisa memberi supply nutrisi yang bagus untuk batang utama, dan bisa mengurangi resiko penyakit akar dan batang.

Tujuan dibuatnya batang tambahan itu sebagai cadangan jika batang utama mati terserang penyakit. Dengan dibuatnya kaki ganda atau kaki tambahan pada batang bibit durian bisa menambah daya serap air dan nutrisi tanaman dari dalam tanah menjadi lebih besar yang bersumber dari serapan akar dari beberapa batang tambahan yang disambung ke batang utama. Tehnik kaki ganda ini mampu meningkatkan kualitas pertumbuhan dan perkembangan tanaman. Hal, terbukti saat tanaman dalam fase bibit tanaman berkaki ganda ini tumbuh lebih cepat dan lebih vigonous disbanding bibit berkaki tunggal. Sayangnya bibit berkaki ganda ini akan terhenti saat volume akar sudah memenuhi seluruh ruang yang ada di polibag. Untuk mengatasi harus cepat segera pindah ke tanah maka, pertumbuhan bibit kaki ganda akan lebih cepat dan maksimal hingga kurun waktu kurang dari 2 tahun, selebihnya 
tanaman akan tumbuh sama dengan tanaman berbatang tunggal. Tujuan penelitian, untuk mengetahui lamanya batang bawah menyatu pada batang utama bibit durian, pengaruh banyaknya kaki ganda terhadap pertumbuhan bibit durian, dan interaksi antar banyaknya kaki ganda dengan lamanya penyatuan batang utama dengan batang tambahan.

\section{METODE PENELITIAN}

Penelitian ini merupakan penelitian lapangan (action research) yang dilaksanakan di salah satu kebun durian siam milik petani di daerah sentra produksi durian di desa Sumberjambe kecamatan Sumberjambe, kabupaten Jember, yang diaksanakan dari tanggal 20 Mei 2018 sampai dengan tanggal 31 Agustus 2018. Pengambilan sampel dilakukan secara purposive sampling dengan kreteria umur bibit durian sama.

Penelitian ini dilaksanakan secara faktorial 3 x 4 dengan Rancangan Acak Kelompok (RAK) yang terdiri dari 2 faktor dan 3 kali ulangan.

Perlakuan masing-masing faktor adalah sebagai berikut:

Faktor I : Lamanya proses penyatuan sambungan bibit durian (L) terdiri dari 3 level, yaitu:

L1 : Penyatuan batang utama dan batang tambahan pada hari ke-40

L2 : Penyatuan batang utama dan batang tambahan pada hari ke-60

L3: Penyatuan batang utama dan batang tambahan pada hari ke 80

Faktor II : Pemakaian jumlah kaki ganda (P) terdiri dari 4 level, yaitu:

P1 : Perlakuan dengan menggunakan 1 batang kaki

P2 : Perlakuan dengan menggunakan 2 batang kaki

P3 : Perlakuan dengan menggunakan 3 batang kaki

P4 : Perlakuan dengan menggunakan 4 batang kaki

Waktu pengamatan dilakukan pada hari ke 40 (L1), hari ke 60 (L2) dan hari ke 80 (L3), variabel yang diamati ialah, tinggi tanaman, diameter batang dan jumlah daun. Data yang terkumpul kemudian dianalisis varian, apabila berbeda nyata maka dilanjutkan dengan uji DMRT (Duncan's Multiple Range Test).

\section{HASIL DAN PEMBAHASAN}

Berdasarkan hasil pengumpulan dan pengolahan data dari masing-masing pengamatan yang dilakukan maka dapat diketahui pengaruh kaki ganda dan lamanya penyatuan terhadap pertumbuhan bibit durian (Durio zibethinus L.). Untuk mengetahui secara garis besar dari masing-masing pengamatan disajikan sebagai berikut:

\section{Tinggi Bibit Tanaman}

Variabel tinggi tanaman diukur pada umur 40 hari, 60 dan 80 hari, diukur dari atas permukaan media tanam sampai titik tumbuh tanaman teratas dengan menggunakan 
penggaris dengan satuan $\mathrm{cm}$. Berdasarkan hasil analisa data pengamatan yang dilakukan pada umur 40 hari dan 60 hari setelah penyambungan, kedua faktor memberikan pengaruh yang berbeda tidak nyata (non significant) terhadap parameter tinggi bibit, demikian pula interaksi lamanya penyatuan batang tambahan yang juga memberikan pengaruh yang berbeda tidak nyata.

Tinggi bibit tanaman pada umur ke 40 hari dan 60 hari pengaruh tidak nyata, dikarenakan sambungan batang tambahan masih mengalami proses pemulihan tanaman, antara lain terjadinya pertautan antara batang tambahan dan batang utama pada penyambungan tanaman, serta pemotongan bagian tanaman menyebabkan jaringan parenkim, dan membutuhkan kalus sedangkan proses terbentuknya kalus membutuhkan waktu yang agak lama.

Proses pembentukan kalus ini sangat dipegaruhi oleh kandungan protein, lemak, dan karbohidrat yang terdapat pada jarigan parenkim karena senyawa tersebut merupakan sumber energi dalam membentuk kalus sehingga unsur hara yang diserap dari dalam tanah dan hasil fotosintesa dari daun digunakan untuk pembentukan kalus saja pada faktor ke-40 hari dan 60 hari setelah penyambungan sehingga tanaman tidak berkembang dan diperoleh nilai yang berpegaruh tidak nyata (non significant) dan belum mampu menyerap unsur hara dari tanah.

Tinggi bibit tanaman pada umur 80 hari setelah penyambungan diperoleh hasil yang berbeda sangat nyata, hal ini dikarenakan pada 80 hari setelah penyambungan, batang tambahan sudah menyatu pada batang utama sehinga batang tambahan bisa menyerap unsu hara dari tanah dan disalurkan ke batang utama sehigga unsur hara tanaman semakin banyak dan terpenuhi maka tanaman akan cepat berkembang. Dengan adanya pengaruh sangat nyata ini maka dilakukan uji lanjut dengan uji DMRT dengan tingkat kesalahan 5\%.

Tabel 1. Pengaruh banyaknya kaki ganda terhadap tinggi bibit durian (Durio zibethinus L.)

\begin{tabular}{|c|c|}
\hline Perlakuan & Tinggi Tanaman pada umur 80 hari $(\mathrm{cm})$ \\
\hline P1 & $45,33 \quad$ a \\
\hline $\mathrm{P} 2$ & $47,33 \quad b$ \\
\hline P3 & $50,89 \mathrm{c}$ \\
\hline $\mathrm{P} 4$ & $47,65 \mathrm{~b}$ \\
\hline
\end{tabular}

Keterangan: Angka-angka yang diikuti oleh huruf yang sama menunjukkan berbeda tidak nyata berdasarkan uji DMRT 5\%

Tinggi bibit tanaman pada umur 80 hari memberikan pengaruh yang nyata (Tabel 1). Pada perlakuan tiga kaki (P3) menunjukkan perbedaan yang nyata dibanding dengan perlakuan satu kaki (P1), dua kaki (P2), dan empat kaki (P4). Perlakuan (P3) memberikan pengaruh yang lebih tinggi. Hal ini dikarenakan pada penambahan kaki ganda dengan menggunakan 3 batang tambahan pada umur bibit 80 hst, sudah menyatu pada tanaman sehigga 2 batang tambahan mampu menyerap unsur hara dari dalam tanah dan disuplai ke batang utama sehingga batang utama menjadi lebih subur dan pertumbuhan makin meningkat dibandingkan yang memakai 1 batang saja, hal ini disebabkan karena faktor unsur hara dalam tanah. Unsur hara $\mathrm{N}, \mathrm{P}$, dan $\mathrm{K}$ yang terkandung dalam tanah dapat memacu pertumbuhan tanaman. Unsur hara $\mathrm{N}$ yang terkandung dalam tanah berperan dalam 
sintesa asam amino dan protein secara optimal, selanjutnya digunakan dalam proses pertumbuhan dan perkembangan tanaman, sedangkan tanaman yang mengalami kekurangan unsur hara $\mathrm{N}$ menyebabkan tanaman menjadi kerdil (Decoteau, 2000 dalam Bahrun, 2012). Selanjutnya dinyatakan bahwa terdapat sinkronisasi antara kadar hara yang tersedia dan kebutuhan tanaman dalam melangsungkan pertumbuhan dan produksi.

\section{Diameter Batang}

Perlakuan sambung batang kaki (P1) memberikan pengaruh yang berbeda sangat nyata terhadap parameter lingkar batang (diameter batang) pada umur 80 hari. Sedangkan pada umur (40 dan 60) hari memberikan pengaruh yang berbeda tidak nyata. Sidik ragam pengamatan lingkar batang umur 80 hari pada faktor (p) dilakukan uji lanjut dengan uji DMRT dengan tingkat kesalahan 5\% yang tersaji dalam Tabel 2.

Tabel 2. Pengaruh banyaknya kaki ganda terhadap diameter batang durian (Durio zibethinus L.)

\begin{tabular}{|c|c|}
\hline Perlakuan & Diameter Batang pada umur 80 hari $(\mathrm{cm})$ \\
\hline P1 & $1,47 \quad \mathrm{a}$ \\
\hline P2 & $1,53 \mathrm{~b}$ \\
\hline P3 & $1,67 \mathrm{c}$ \\
\hline P4 & $1,60 \mathrm{~b}$ \\
\hline
\end{tabular}

Keterangan: Angka-angka yang diikuti oleh huruf yang sama menunjukkan berbeda tidak nyata berdasarkan uji DMRT 5\%

Perlakuan penambahan 3 batang kaki (P3) mampu menghasilkan lingkar batang terbesar 1,67 cm, sedangkan penambahan memakai 2 batang kaki (P2) dan 4 batang kaki (P4) menghasilkan lingkar batang yang sedikit berbeda yaitu 1,53 cm untuk (P2) dan 1,60 $\mathrm{cm}$ (P2). Saat tanaman berumur 80 hari memberikan pengaruh yang sangat nyata antara 3 kaki (P3) terhadap terhadap 2 kaki (P2) dan 4 kaki (P4) (Tabel 2). Hasil tersebut menunjukkan bahwasanya perlakuan 3 kaki (P3) memberikan pengaruh terhadap lingkar batang.

Lingkar batang pada parameter pengamatan umur (40 dan 60) hari memberikan pengaruh yang berbeda tidak nyata terhadap pertumbuhan dan perkembangan diameter batang. Hal ini disebabkan karena nutrisi pada batang tambahan belum mampu diserap oleh batang utama, sehigga batang tambahan tidak berkembang. Apabila tanaman tidak memiliki suplai nutrisi yang cukup maka pembesaran dan perpanjangan sel terhambat. Pada umur (40 dan 60) hari batang tambahan belum mampu menyerap nutrisi karena batang tambahan belum menyatu pada batang utama dengan demikian pengaruh yang diberikan khususnya perkembangan batang belum tampak pada saat tanaman sebelum berumur 80 hari, sehingga dapat diketahui bahwa semua perlakuan, baik penambahan kaki ganda dan lamanya penyatuan batang tambahan secara keseluruhan menunjukkan perbedaan yang nyata terhadap parameter diameter batang umur 80 hari. Hal ini disebabkan karena faktor unsur hara dalam tanah. Semakin banyak jumlah sambungan kaki bawah nutrisi yang diperoleh semakin meningkat karena penyerapan unsur hara berbeda sehingga batang utama akan 
cepat tumbuh dan berkembang dan meghasilkan diameter yang lebih besar dibandingkan perlakun pada faktor ke (40 dan 60) hari. Hal ini dapat dibuktikan dengan hasil uji Duncan yang menunjukkan bahwa nilai tertinggi berada pada P3 dan nilai terendah terjadi pada P1 dengan nilai $1,47 \mathrm{~cm}$.

\section{Jumlah Daun}

Berdasarkan hasil analisa data pengamatan yang dilakukan pada umur 40 hari dan 60 hari setelah sambung batang kaki, kedua faktor tersebut memberikan pengaruh yang berbeda tidak nyata (non significant) terhadap parameter jumlah daun, demikian pula interaksi lamanya penyatuan batang tambahan yang juga memberikan pengaruh yang berbeda tidak nyata. Dengan begitu, maka tidak dilakukan uji lanjut pada parameter jumlah daun pada umur (40 dan 60) hari setelah sambung batang kak. Pengaruh tidak nyata pada umur (40 dan 60) hari setelah sambung batang kaki dikarenakan sambungan batang masih belum menyatu sehingga masih belum bisa menyerap unsur hara yang ada di dalam tanah, dan mengakibatkan batang tambahan belum bisa menyalurkan nutrisi yang diserap dari dalam tanah dengan demikian tanaman tidak cepat berkembang baik dari tinggi tanaman maupun jumlah daunnya.

Jumlah daun pada umur 80 hari setelah sambung batang kaki berpengaruh sangat nyata. Hal ini dikarenakan batang sambungan sudah mulai menyatu dengan batang utama walaupun tidak maksimal sehingga batang sambungan sudah mulai bisa menyerap nutrisi yang ada. Sedangkan pada umur 80 hari memberikan pengaruh yang berbeda sangat nyata hal ini dikarenakan batang tambahan sudah mampu menyalurkan nutrisi yang diserap dari dalam tanah sehingga mengakibatkan banyaknya jumlah daun yang dipengaruhi oleh diameter batang yang kecil mempunyai jumlah calon mata tunas yang lebih banyak sehingga akan menghasilkan tunas yang baru dengan jumlah daun dalam tunas yang lebih banyak. Dengan adanya pengaruh yang berbeda nyata dan berbeda sangat nyata pada umur 80 hari setelah sambung batang kaki maka dilakukan uji lanjut DMRT ((Duncan's Multiple Range Test ) dengan tingkat kesalahan 5\% yang tersaji dalam Tabel 3.

Tabel 3. Pengaruh banyaknya kaki ganda terhadap jumlah daun pada bibit durian pada umur 80 hari (Durio zibethinus L.)

\begin{tabular}{|c|c|}
\hline Perlakuan & Jumlah Daun pada umur 80 hari \\
\hline P1 & $10,44 \quad \mathrm{~b}$ \\
\hline $\mathrm{P} 2$ & $9,67 \quad \mathrm{a}$ \\
\hline P3 & $13,55 \mathrm{c}$ \\
\hline $\mathrm{P} 4$ & $10,78 \quad b$ \\
\hline
\end{tabular}

Keterangan : Angka-angka yang diikuti oleh huruf yang sama menunjukkan berbeda tidak nyata berdasarkan uji DMRT 5\%

Pada umur bibit durian sudah berumur 80 hari (Tabel 3) penambahan kaki ganda nampak pada hasil yang didapatkan oleh (P3) dengan nilai tertinggi 14 lebih dibandingkan yang memakai empat batang tambahan (P4) dengan rata-rata jumlah daun 11 dan diikuti dengan (P1) dengan rata-rata jumlah daun 10 (pembuatan dari 10,44) helai daun, sedangkan 
nilai terendah didapat pada (P2) dengan rata-rata jumlah daun 10 (pembulatan dari 9,67). Pada umur 80 hari, memberikan pengaruh yang berbeda sanggat nyata terhadap semua perlakuan mulai dari (P1) terhadap perlakuan (P2), (P3), dan (P4). Hasil tersebut menunjukkan bahwasanya perlakuan penambahan kaki ganda memberikan pengaruh terhadap jumlah daun.

Secara umum terlihat bahwa perlakuan (P3) pada faktor perlakuan hari ke 80 memperlihatkan hasil yang lebih baik dibandingkan dengan kombinasi perlakuan yang lainnya. Dan dari perhitungan analisis sidik ragam hasil tersebut memberikan pengaruh yang berbeda sangat nyata terhadap jumlah daun. Hal ini dikarenakan faktor kondisi lapisan kambium masing-masing sel tanaman baik batang tambahan dan batang utama membetuk kalus berupa sel-sel parenkim yang saling kontak menyatu dan membaur, sehingga sel-sel parenkim yang terbentuk akan terdifrensiasi membentuk kambium sebagai lanjutan dari lapisan kambium batang tambahan dan batang utama yang lama, dari lapisan kambium akan terbentuk jaringan pembuluh sehingga proses translokasi unsur hara dari batang tambahan ke batang utama bisa berlangsung dengan baik.

\section{KESIMPULAN}

1. Perlakuan penambahan kaki ganda memberikan pengaruh terhadap tinggi bibit durian, diameter batang, dan jumlah daun pada umur 80 hari setelah sambung kaki. Penambahan kaki ganda dengan tiga kaki memberikan hasil terbaik terhadap penyambungan.

2. Perlakuan lamanya penyatuan sambungan hari ke-(40, 60 dan 80) tidak memberikan pengaruh terhadap parameter tinggi bibit tanaman durian, diameter batang, dan jumlah daun.

3. Interaksi antara penambahan kaki ganda dan lamanya penyatuan tidak memberikan pengaruh terhadap pertumbuhan bibit durian.

\section{DAFTAR PUSTAKA}

Bahrun, A. 2012. Pengaruh Bahan Organik Dan Pupuk Kalium Terhadap Pertumbuhan dan Produksi Tanaman Melon (Cucumis melo L.). Dalam Jurnal Online Agroteknos 8(2) : 69-76 ISSN 2087-7706. Kendari. [ 20 Mei 2015 ].

Direktorat Jenderal Hortikultura. 2012. Statistik Produksi Hortikultura Kementerian Pertanian. Jember Information Centre, 2015. www.jemberjic.com. Duriansumberjambe

Gardner, F. P, R. B Perace dan R. L Mitchell. 1991. Fisiologi Tanaman Budidaya. Terjemahan Herawati Susilo. UI Press. Jakarta.

Hidayat, E. B. 1995. Anatomi Tumbuhan Berbiji.Cetakan ke-1.Institut Teknologi Bandung. Bandung.

Institut Pertanian Bogor. 2012. Program Peningkatan Produksi Tanaman Durian. Pusat Studi Pembangunan Pertanian dan Pedesaan. Lembaga Penelitian dan Pengabdian Masyarakat. http://psp3.ipb.ac.id [diakses Oktober 2014]. 
Irawanata, M.H.Y.2017. Durian Sumber jambe-Mutiara dari Timur Pulau Jawa.umy.ic.id. http://duriodurian.blogspot.com/2013/05/mutiara-terpendam-desa-sumberjambe. Html.

Pusat Data dan Sistem Informasi Pertanian. 2013. Statistik SDM, Penduduk dan Kemiskinan. Jakarta: Pusat Data dan Sistem Informasi Pertanian, Kementerian Pertanian.

Rukmana, R., 1996. Durian.Budidaya dan Pasca Panen. Kanisius, Yogyakarta.

Santoso, Budi, 1992, Sifat dan Ciri Tanah Latosol, Komunikasi Ilmu Tanah Fakultas Pertanian Universitas Brawijaya, Malang.

Setiadi. 1999. Bertanam Durian. Penebar Swadaya. Jakarta.

Soedarya, A.P. (2009). Agribisnis Durian. Penerbit CV Pustaka Grafika, Bandung.

Subhadrabandhu, S., J.M.P. Schneemann and E.W.M Verheij, 1991, Durio zibethinus Murray.dalam Veheiij, E.W.M., dan R.E. Coronel, R.E. (eds). Plant Resources of South-east Asia. No. 2, Edible Fruits and Nuts, PUDOC, Wageningen, pp. 157-161.

Verheij, E.M.W dan R. E Coronel, 1997. Sumber Daya Nabati Asia Tenggara, Buah-Buahan Yang Dapat Ditanam. Terjemahan S. Somaatmadja. Gramedia Pustaka Utama. Jakarta.

Wijaya, A. 2013. Seri Bercocok Tanam Bertanam Durian. Ganeca Exact. Bandung. 